\title{
POST-KIMBERLITE EOCENE STRATA WITHIN A CRATER BASIN, LAC DE GRAS, NORTHWEST TERRITORIES, CANADA
}

\author{
A.P. Hamblin ${ }^{1}$, L.D. Stasiuk ${ }^{1}$, A.R. Sweet ${ }^{1}$, G.D. Lockhart ${ }^{2}$, D.R. Dyck ${ }^{2}$, K. Jagger ${ }^{3}$ and L.R. \\ Snowdon ${ }^{1}$
}

${ }^{1}$ Natural Resources Canada, Geological Survey of Canada, Calgary, Alberta, Canada; ${ }^{2}$ BHP Billiton Diamonds Inc., Kelowna, Canada; ${ }^{3}$ Geography and Earth and Environmental Sciences, Okanagan University College, Penticton, B.C.

\begin{abstract}
Sedimentology, organic petrology-geochemistry and palynology have been integrated to study fine-grained, siliciclastic Eocene sediments deposited within a small kimberlite crater basin, Lac de Gras, Northwest Territories, Canada. The strata represent a shallowing-upward succession of lake basin-fill including three stratal units: a lower unit of dark organic-rich mudstone $(\%$ total organic carbon: TOC $=$ $15-50 \%$ ) interpreted as low energy, shallow sub-lacustrine deposition; a thin transitional unit with evidence of near surface exposure $(\mathrm{TOC}=2-12 \%$ ); and an upper unit characterized by thick peat bog deposits (TOC $=39-55 \%$ ). Both upper and lower portions of the sediments are characterized by shallowing-upward, higher order sequences suggesting cyclic climatic wet/dry phases. Their boundaries correspond with marked changes in TOC, and Rock-Eval hydrogen and oxygen indices. The combined presence of Pistillipollenites mcgregorii, and forms of Platycarya restricts the age of the Giraffe sediments to late early to early middle Eocene. These taxa do not occur in the upper part of the core which may only reflect a shift in depositional environment. The distribution and type of microscopic organic matter reflects the sedimentological observations with the lower, lacustrine zone consisting of abundant diatoms, chrysophytes and liptinites (e.g. sporinite, alginite), and the upper, peat bog zone consisting predominantly of woody macerals. Huminites through the section have reflectance values averaging 0.23 $\%$ Ro, indicating that thermal maturity is slightly greater than modern peats and that post-kimberlite burial and thermal alteration have been insignificant with temperatures no greater than $\sim 30^{\circ} \mathrm{C}$.
\end{abstract}

\section{INTRODUCTION}

The "Giraffe Pipe" is a kimberlite occurrence, located $25 \mathrm{~km}$ northeast of the Ekati Diamond MineTM, within the Lac de Gras kimberlite field, Northwest Territories, Canada. It has an emplacement model age of $47.4+-0.5 \mathrm{Ma}$ (middle Eocene), based on a Rb-Sr age of kimberlitic phlogopite. The discovery drill hole, collared at $-47^{\circ}$, encountered sedimentary strata at downhole depths of 50 to 160 metres. These strata were, presumably, deposited in a micro-basin setting $(\sim<250 \mathrm{~m}$ diameter) within the open vent of the pipe, after kimberlite emplacement. An excellent quality core was examined and sampled in detail for the purpose of assessing the paleodepositional environment, age, level of thermal maturity, and bulk organic chemical properties with respect to quality of peat and/or oil shale. This paper presents a summary of the results from sedimentology, organic petrology, organic geochemistry and palynology studies of the Giraffe sediments. For a summary of the experimental procedures used in this study see Stasiuk et al., (2003, this volume) or Stasiuk et al., (2002).

\section{RESULTS AND DISCUSSION}

\section{Age, Sedimentology, and Paleoenvironment}

The sedimentary succession in the Giraffe core is divisible into several stratal units. The lower interval $(160-99 \mathrm{~m})$ is dominated by dark organic-rich mudstone, the upper portion $(97-50 \mathrm{~m})$ is dominated by brown muddy peat, and a thin transition zone between (105-97 $\mathrm{m}$ ) has abundant roots, thin bentonite beds and vegetative hash layers (Fig. 1). Palynology age dating has used the presence of Pistillipollenites mcgregorii in the interval between 86 and $132.4 \mathrm{~m}$ (Fig. 1) as an upper age limit of middle Eocene on the core according to the age range ascribed to this species by Rouse (1977). The earliest occurrence of Platycarya is used as an indicator of the beginning of the Eocene in western North America (Wing, 1984). The particular form of Platycarya present in the core has been recorded from the lower Eocene of southeastern United States (Frederiksen and Christopher, 1978). Boehlensipollis granulatus has been reported from middle Eocene (Frederiksen, 1983) and inferred upper Eocene strata (Ridgeway et al. 1995). Other flowering plant or angiosperm taxa recorded in the core that support an early to middle Eocene age include Carya, Castanea, Celtis, Cayaponia-type pollen, Engelhardtia, Ericaceae pollen, Fagus, Ilex, Juglans, Quercoidites, Pterocarya, Rhododendron, Symplocos arcuata and Tilia vescipites. The lack of correspondence between a) the relative abundances within the palynoflora (Fig. 1), and b) the lithological and geochemical characteristics described below, indicates that most pollen was transported into the crater sediments from vegetation growing in the wider surrounding region. The few recorded up-section changes in the pollen flora may, therefore, primarily reflect external factors such as climatic variations. 


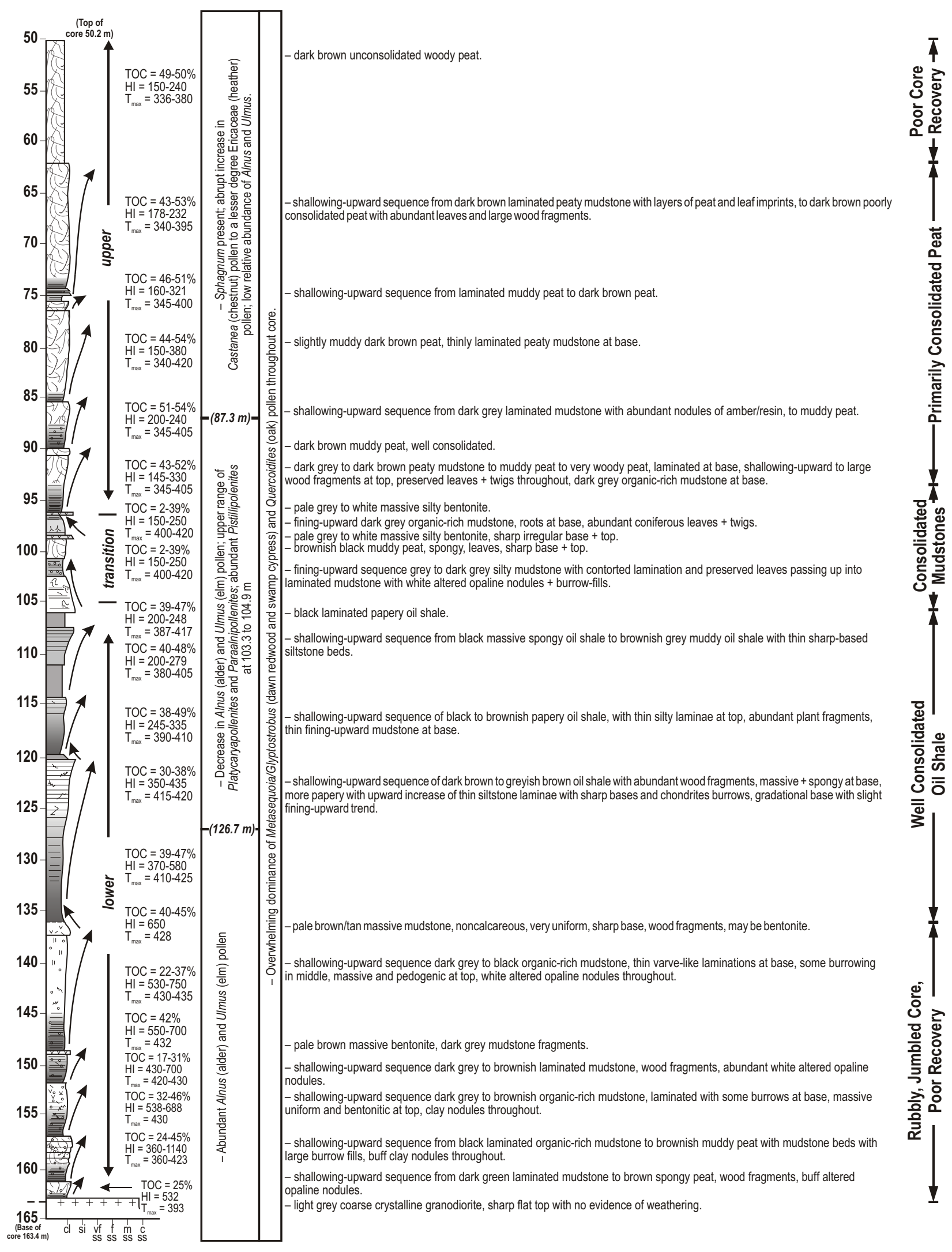

Figure 1. Description and detailed sedimentological column and interpretation of paleoenvironments with corresponding abstracted palynological data, and Rock-Eval data showing range of total organic carbon (wt \%TOC), hydrogen index (mg $\mathrm{HC} / \mathrm{gTOC}$ ) and oxygen index (mg CO2/g TOC). 


\section{Lower Zone}

The core interval between 160 and $99 \mathrm{~m}$ depth in the "Giraffe Pipe" is predominantly dark brownish grey to dark brown to black, organic-rich mudstone or oil shale (Fig. 1). It sharply overlies granodiorite with no obvious weathering profile, but thin units of brown spongy peat occur near the base. Tiny horizontal Chondrites-like burrows are present in many units. Siltstone laminae, up to $1 \mathrm{~cm}$ thick, with sharp bases and tops are common and these thinly interbedded lithologies are arranged into small coarsening-upward sequences 2-15 m thick. This interval is interpreted to represent open quiet lacustrine sedimentation with very little clastic input beyond suspended clays and essentially no wave/current energy. The $\mathrm{mm}$ - to $\mathrm{cm}$-scale siltstone beds are interpreted as sudden, minor influxes of clastic material from the margins, perhaps in response to storms. Depth of subaqueous deposition was likely shallow, a few tens of metres at most, and the lack of higher energy and coarser clastic input suggests deposition near the centre of this areally small body of freshwater. The basement surface was rapidly inundated, with little time for regolith development, and the lower $10 \mathrm{~m}$ represent a generally deepening-upward, transgressive tract. The rest of the depositional motif is dominated by subtle, but discernible, coarsening-upward sequences, interpreted as shallowingupward lake-basin fill sequences, or progradational tracts, representing periodic wet/dry climatic phases. Abundant, well-preserved organic matter and plant fossils suggest a relatively humid climate and reducing conditions. Several periods of possible subaerial exposure are recorded at the tops of some sequences by a) thin 0-2 m bentonite beds, b) thin 1-3 $\mathrm{m}$ peat units and $\mathrm{c}$ ) a possible pedogenically-altered brownishgrey mudstone.

Overall Total Organic Carbon contents in this zone range from $>15$ to $<50 \%$ and show a progressive increase upward toward the 'transition zone' (Fig. 2). There is a good correspondence between sedimentological unit boundaries and marked increase-decrease changes in TOC (Fig. 2). Hydrogen indices in the lower zone progressively decrease with decreasing depth whereas oxygen indices progressively increase with decreasing depth (Fig. 3). The vertical distribution of TOC, HI and OI are typical of a progressive, shallowing and terrestrialization through time from a lacustrine towards a bog/swamp paleodepositional setting. The maceral and microfossil composition of the lower section also reflects a dominantly lacustrine assemblage of organic material near the base of the zone consisting of assemblages of abundant fluorescing amorphous liptinite, sporinites, fresh to brackish water Botyrococcus alginites, diatoms and chrysophytes, with varying amount of huminite, woody derived matter. The amount of woody huminite increases progressively whereas alginite decreases progressively, with decreasing depth, reflecting progressive terrestrialization from an open water lacustrine to bog environment.

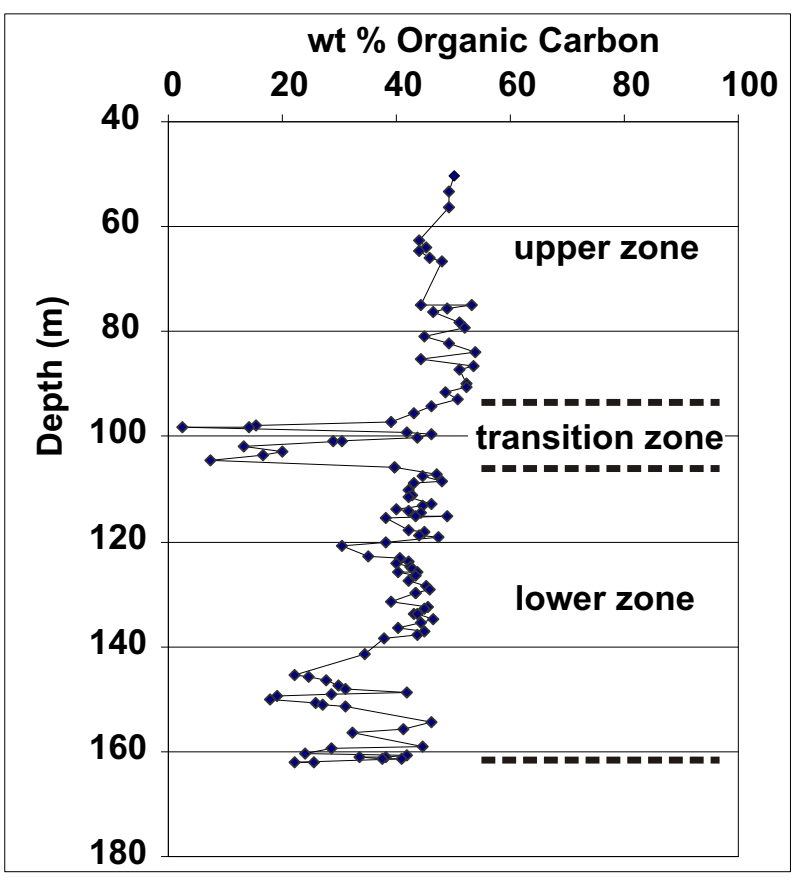

Figure. 2. Distribution of Total organic carbon contents (wt \%) in Giraffe pipe sediments.

\section{Transitional Zone}

Between 105 and $97 \mathrm{~m}$ depth sediments consist of dark grey laminated mudstone with abundant roots, silty mudstone with contorted lamination, thin white bentonite beds, muddy peats, and surfaces covered in well-preserved coniferous twigs and needles. This heterogeneous unit is interpreted to represent a transition zone between the predominantly subaqueous lacustrine mudstones below and the predominantly subaerial peats above. It thus marks the approximate chronostratigraphic point in time where the lake basin ceased to be a body of open water and was converted to a bog setting. It is dominated by indicators of near-exposure: roots, the lowest occurrence of peat, well-preserved very thin bentonite beds and well-preserved higher plant matter.

Rock-Eval pyrolysis data defines a similar transition zone, from lacustrine to bog, compared with sedimentological features. Between 105 and $98 \mathrm{~m}$ depth, there as a marked reduction in TOC contents (from $\sim 40 \%$ down to $2-12 \%$ ) followed by a sharp increase and, then another reduction (Fig. 2 ). Similarly hydrogen indices show a reduction (from $\sim 250$ to $<100 \mathrm{mg} \mathrm{HC} / \mathrm{gTOC}$ ) and then a marked increase to values $>$ 800 (Fig. 4). This likely represents a period of instability in the organic productivity, input and preservation potential of the paleoenvironment related to rapidly alternating sub-aerial exposure and submersion, and perhaps a disruption by volcanic activity as indicated by bentonites.

\section{Upper Zone}

The core interval $97-50 \mathrm{~m}$ is predominantly dark brown to grey 
to light brown, muddy peat, fairly well consolidated (except at the top of the core), in places quite woody and with some large leaf imprints, large wood fragments and roots. In upper parts of the core the peat is so well-preserved that it is reminiscent of modern everyday bagged garden peat. Abundant tiny nodules of amber or resin are present in some portions. These deposits are also arranged in coarsening-upward sequences 5-13 m thick, passing from thin units of dark grey laminated organicrich mudstone at their bases to thick peat units. This interval is interpreted to represent subaerial marsh/bog/fenland deposits with little open water and essentially no clastic input beyond minor suspended clay sedimentation. It represents the final fill stage of this lake basin where vegetative mats of organic matter extended outward from the margins to cover the surface with a wetland setting. The abundant preservation of organic matter suggests a relatively humid climate. Water depths here were likely never more than a few metres at this stage. However, interestingly, the depositional motif is still dominated by subtle coarsening-upward sequences, interpreted as progradational shallowing-upward lake-basin fill sequences, or vegetative clogging sequences. This suggests the continuation of multiple periodic wet/dry climatic phases. Changes in TOC and HI values in the upper zone of "Giraffe Pipe" strata correspond very well with the sedimentological defined transition from lower, to upper zone (compare Figs. 1, 2, and 3).
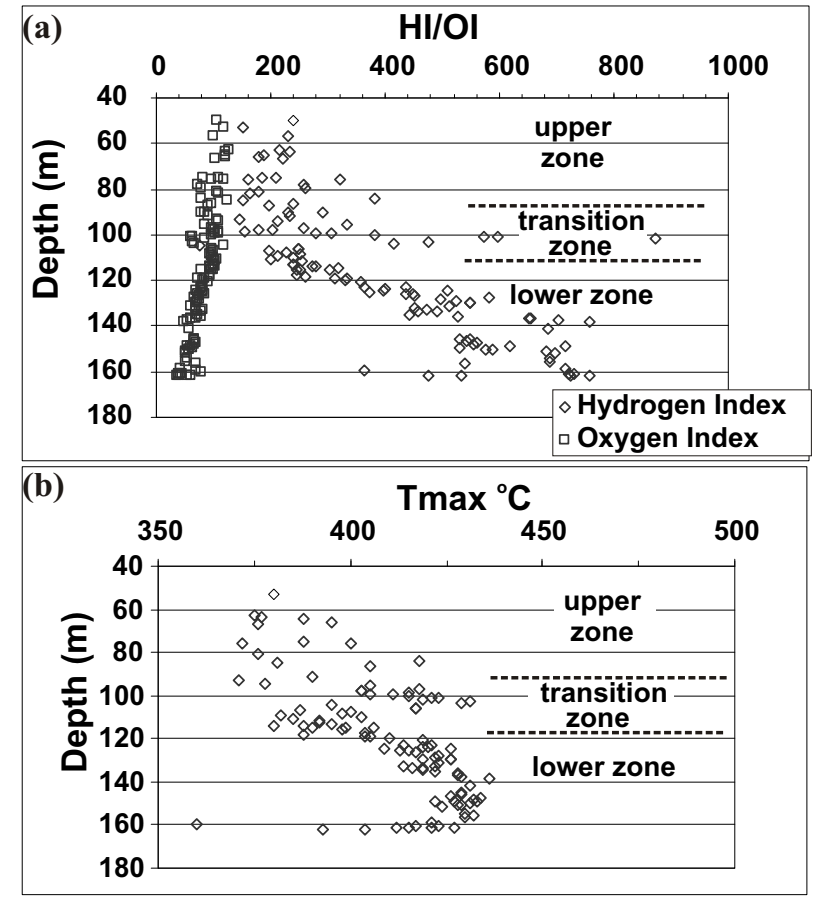

Figure 3. a) Distribution of hydrogen (mg HC/gTOC) and oxygen indices (mg CO2/g TOC) and b) Tmax values from pyrolysis experiments through Giraffe pipe sediments.

Overall, the amount of TOC in the upper, bog zone exceeds that of the lower, lacustrine zone (ranging from 39 to $55 \mathrm{wt} \%$, Fig. 2). However the vertical profile of TOC against depth in the upper zone is on trend with the lower profile suggesting either a steady progressive increase in productivity and preservation
Overall, the amount of TOC in the upper, bog zone exceeds that of the lower, lacustrine zone (ranging from 39 to $55 \mathrm{wt} \%$, Fig. 2 ). However the vertical profile of TOC against depth in the upper zone is on trend with the lower profile suggesting either a steady progressive increase in productivity and preservation of organic matter with time as the bog was established combined with a progressive reduction in amount of external inorganic sediment being fed into the lacustrine-bog system. Alternatively, an increase in TOC with decreasing depth could result from increasing rate/degree of diagenetic mineralization of organic matter with increasing depth, although this is unlikely considering the great degree of change in TOC over such a short distance. The much lower Hydrogen, and higher Oxygen indices in the upper section compared with the lower zone reflect differences in organic matter types in the 2 zones, a direct consequence of different depositional environments. The lower zone contains more open water, hydrogen- rich liptinite macerals such as amorphinite, sporinite, cutininte, and alginite, whereas the upper zone is dominated almost exclusively by carbon- and oxygen-enriched, wood-derived macerals such as huminite.

\section{Thermal Maturity}

Per cent reflectance in oil (\%Ro) data for huminite/vitrinite macerals in the "Giraffe Pipe" range from 0.17 to $0.28 \%$ Ro, with a mean of $0.23 \%$ Ro (Figure $4 a$ ). The mean \%Ro is only slightly greater than ' zero' coalification, or the mean \%Ro of 0.18 - 0.20 for modern surface peats which have not undergone burial diagenesis. Thus in terms of thermal maturity level, organic matter in Giraffe pipe still has not seen any significant amount of burial since deposition, nor has it been exposed to temperatures any higher than $\sim 20$ to $30^{\circ} \mathrm{C}$. The excellent preservation of the delicate opalline skeletons of the chrysophytes in the lower zone sediments also attests to the very low level of thermal alteration and lack of compaction of the strata.

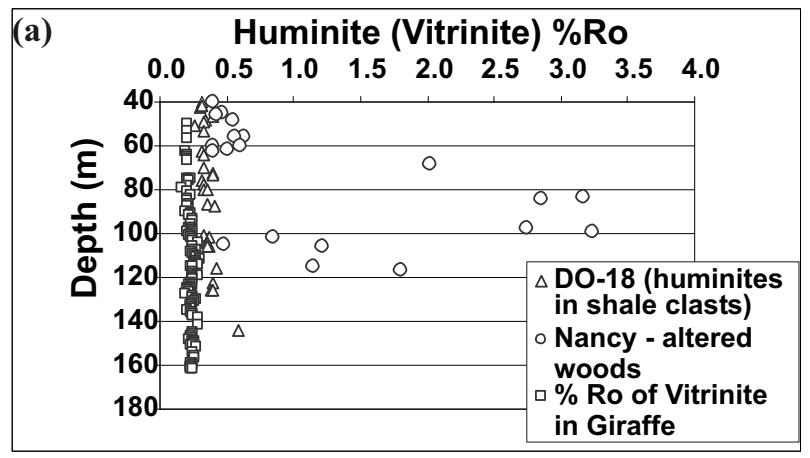

Figure 4. a) Plot of depth versus per cent reflectance in oil (\%Ro) of huminite-vitrinite organic matter in the Giraffe pipe sediments.

A comparison of \%Ro based thermal maturity levels for Eocene Giraffe sediments, Cretaceous Albian to Cenomanian unaltered shale xenoliths in kimberlite pipe 
crater facies from DO18 (see Doyle et al., 1998) and from Paleocene woods thermally altered during kimberlite emplacement, is shown in Figure 4b. The relative difference in vitrinite \%Ro emphasizes and highlights the different thermal histories of organic matter within these 3 different settings in the Lac de Gras kimberlite field.

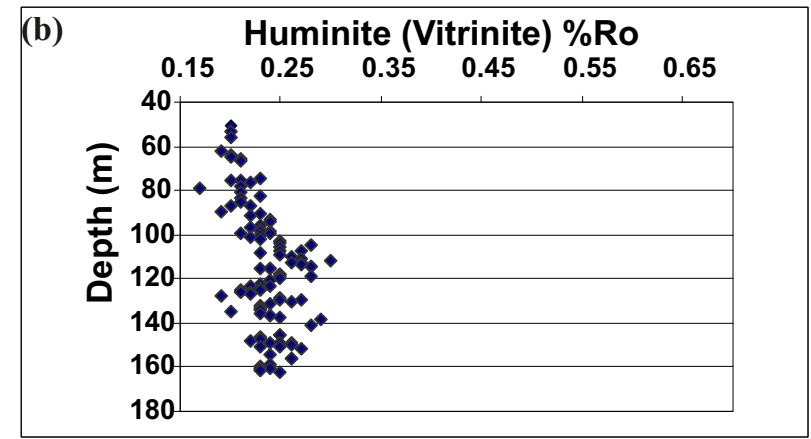

Figure 4. b) Plot of depth versus per cent reflectance in oil of huminite and vitrinite macerals in Lac de Gras area, for Giraffe pipe Eocene sediments, Cretaceous shale xenoliths from DO18 kimberlite, Tli Kwi Cho kimberlite field (see Stasiuk et al., 2003, this volume), and Tertiary woods altered during kimberlite emplacement of Nancy pipe.

crater facies from DO18 (see Doyle et al., 1998) and from Paleocene woods thermally altered during kimberlite emplacement, is shown in Figure $4 \mathrm{~b}$. The relative difference in vitrinite $\%$ Ro emphasizes and highlights the different thermal histories of organic matter within these 3 different settings in the Lac de Gras kimberlite field.

\section{SUMMARY}

The overall setting, then, is one of a small, low-energy lake basin of early to early middle Eocene age which was filled by a single complex sublacustrine to subaerial succession, with minimal clastic input or carbonate precipitation. This succession is characterized by multiple stacked higher-order shallowing-upward sequences, which likely extended over the entire micro-basin. There was a continuous upward increase in shallowing and exposure periods from dominantly subaqueous suspended sediments to dominantly subaerial vegetative mat sediments as the basin filled and the marginal vegetative mats grew outward to clog the surface. This is a common process in modern, small freshwater basins present in humid climates. There was a concomitant upward change from thermally immature lacustrine organic-rich mud and oil shale, to thermally immature terrestrial bog deposits.

\section{ACKNOWLEDGMENTS}

The authors would like to thank Jon Carlson and Tony Gonzalez of BHP Billiton Diamonds Inc., Kelowna, for their financial and logistical support. Technical assistance was provided by Maria Tomica, Kim Dunn, Linda Dancey, Brenda Davies, and Dr. Ramakant Kalgutkar.

\section{REFERENCES}

Doyle, B.J, Kivi, K. and Scott Smith, B.H. 1998. The Tli Kwi Cho (DO27 and DO18) diamondiferous kimberlite complex, Northwest Territories, Canada. In Proceedings of the Seventh International Kimberlite Conference, I.J. Gurney, J.L. Gurney, M.D. Pascoe and S.H. Richardson (eds.), Capetown, v. 1,pp. 194-204.

Frederiksen, N.O., 1983. Middle Eocene palynomorphs from San Diego, California, Part II. Angiosperm pollen andmiscellanea: AASP Contribution Series, No. 12, pp. 32154.

Frederiksen, N.O., and Christopher, R.A., 1978. Taxonomy and biostratigraphy of late Cretaceous and Paleogene triatriate pollen from South Carolina: Palynology, v. 2, pp. 113145.Ridgeway, K.D., Sweet, A.R. and Cameron, A.R. 1995. Climatically induced floristic changes across the EoceneOligocene transition in the northern high latitudes, Yukon Territory, Canada. Geological Society of America Bulletin, v. 107, pp. 676-696.

Rouse, G.E. 1977. Paleogene palynomorph ranges in western and northern Canada: In Elsik, W.D., ed., Contributions of Stratigraphic Palynology: Cenozoic Palynology, v. 1, pp. 4865.

Stasiuk, L.D., Sweet, A.R. and Issler, D.R. 2002. Organic petrology, organic geochemistry, palynology and petrophysics data from Lac de Gras kimberlites and associated sedimentary rocks and xenoliths. Geological Survey of Canada Open File 4272. CD.

Stasiuk, L.D., Sweet, A.R., Issler, D.R. Kivi, K, Lockhart,G. and Dyck, D.R. 2003. Pre- and post-Kimberlite Emplacement Thermal history of Cretaceous and Tertiary strata, Lac de Gras, Northwest Territories, Canada. 8th International Kimberlite Conference, Victoria Canada.

Wing, S.I. 1984. A new basis for recognizing the Paleocene/Eocene boundary in Western Interior North America . Science, v. 226, pp. 439-441. 